\title{
The implementation of e-Learning in the continuous training of the military of the Republican National Guard. Case study: Lisbon Territorial Command
}

\author{
Liliana SOBReIRA ${ }^{1}$, DAvid PASCOAl Rosado ${ }^{2}$, Helga SANTA COMBA LoPES ${ }^{3}$, \\ MARIA JOSÉ SOUSA ${ }^{4}$ \\ 1 Academia Militar/CINAMIL, PorTUGAL \\ 2 Academia Militar/CINAMIL \& Universidade Europeiam, PORTUGAL \\ 3 Academia Militar/CINAMIL \& Instituto Politécnico da Lusofonia, PORTUGAL \\ ${ }^{4}$ Instituto Universitário de Lisboa \& Business Research Unit, PORTUGAL
}

\begin{abstract}
The training needs felt in the professional path of the military of the Republican National Guard, associated with the potential of using new technologies is the core of this investigation. Training is one of the great challenges that organizations currently face and, in the National Republican Guard, it plays a fundamental role in the service provided by the Institution, making it clear the high importance of acquiring and maintaining knowledge and skills for the performance on several roles in the organization. The present investigation aims to determine the importance of the e-Learning tool for the continuous training of the soldiers of the National Republican Guard. In this context, it is intended to characterize the importance of continuous training whose objective is to identify and analyze the consequences of the tool, as well as to identify the impact of the use of new technologies in the training of the institution's military, according to a case study in the Lisbon Territorial Command. The method that supports the investigation is the deductive method, which is based on a logic from the general to the particular. In order to achieve the defined objectives, we opted for interviews and a questionnaire survey, complemented with a documentary analysis resulting from bibliographic research and institutional documents. Thus, it appears that continuous training has a high importance for the professional development of the military, since it promotes quality in the service provided, positively affecting the daily activities of the military, increasing individual success and, consequently, organizational success . It is concluded that e-Learning represents an asset for continuous training, since it is a catalyst for the potential of the institution's human resources.
\end{abstract}

Keywords: Competencies; e-Learning; Continuing education; Organizations.

\section{Introduction}

The present investigation aims to determine the importance of the implementation of e-Learning in the continuous training of the Republican National Guard military. The Republican National Guard over the years, has shown interest in implementing a more comprehensive e-Learning system, in order to take advantage and enhance the use of equipment and mobile networks that facilitate the interaction of the training entity, teachers and students [1]. The study tool is already present in some courses taught at the Institution, although it is not in its entirety. In this way, the object of study focuses on the analysis of the importance of e-Learning in the continuous training of the Republican National Guard military, having as a case study the Lisbon Territorial Command. Given that organizations are constantly changing due to competition and the growing demand at national and international levels, it is necessary to monitor them in order to achieve certain objectives. In this sense, training is one of the major challenges that organizations currently face, since human resources are a major factor in the success of an organization. On the other hand, competition is a current reality of organizations and, in order for them to obtain competitive advantage in the market, they need their human resources to have qualified training, with a great need for technical skills and qualities at this level [2]. 
Over the years, companies' view of training has adopted disparate forms and perspectives of importance, with the concept of no return investment gradually being abandoned, and it is seen as a medium and long term investment with visible and significantly positive results [3].

The diverse socio-economic and technicalorganizational changes lead to the growing importance of continuing education. The demand of the market is increasing, the globalization of the economy and the increase in competition force organizations to adapt their offer to the needs of customers, in relation to the diversity, quality and quantity of products and innovation $[4,5]$.

In an organization, the high professional competence and technical qualities of workers are at the heart of meeting organizational goals. Consequently, training is the primary element to empower an organization's human resources and, therefore, it should be seen as a necessary investment and a catalyst for an institution's potential. Therefore, for organizational success to be achieved, organizations need workers with high skills and abilities [2].

In addition, over the years, organizations have found that, in order for their workers to perform their functions efficiently and effectively, it was necessary to invest in their continuous training, in order to update and improve their knowledge acquired in initial training [3].

Due to the demands of the market, organizations increasingly promote professional training, not because it is stipulated by law, but rather to motivate workers and improve their work performance, leading to greater growth and development [2]. Training in organizations is very important in terms of "improving professional skills, updating knowledge" and "responding to problems and failures in the execution of jobs" [6].

That said, it is imperative to implement new programs aimed at promoting continuing vocational training, aimed at companies, training and human resources specialists, representatives of employers and workers, seeking to streamline the design of training and provide good professional training practices continues [7].

Depending on their objectives, organizations adopt different types of training, as well as different methods and techniques. the types of training are as follows: integration and orientation training, functional technical training, training for the development of desirable behaviors, training for group development, training in the job or on the job, training for development and support and selfdevelopment actions [8].

Integration and orientation training concerns initial training and aims to integrate the individual, that is, it provides the individual with essential social skills to adapt to the organization as quickly as possible, in order to perform their tasks correctly. Functional technical training aims to update the individual, so that he improves his knowledge and technical skills so that the performance of his work increases. Training for the development of desirable behaviors is associated with the conduct that the organization wants the individual to have, and for that, it is necessary to have training in order to modify or develop the behaviors considered appropriate by the organization. Training for group development aims to promote teamwork and increase interpersonal relationships. On-the-job or on-the-job training takes place at the same time as the individual performs his daily tasks, enabling him to perform new tasks or to use new technologies to perform his usual tasks. Training for personal development is based on the individual himself. It focuses on your personal and social development, in order to make you a better professional. Support and self-development actions come from the organization, so that the individual has the initiative to attend complementary courses or programs. That said, each organization chooses the type of training that suits its objectives and needs, which results in better results and produces greater organizational development.

Over the years, due to technological development, new teaching methodologies have emerged. Distance Learning, which is one of the great examples of these new methodologies, promoted a greater contact between Information and Communication Technologies with education and training. E-Learning emerges as a variant of this modality, consisting of a student-centered teachinglearning process, using virtual environments that, whether applied in isolation or combined with faceto-face teaching, constitutes a tool with high potential in education and training in organizations and on an individual basis [9].

E-Learning is a set of solutions made available by internet technologies, which enhance the knowledge and development of the individual. The term commonly used in Portuguese is distance learning, which according to several authors, includes other forms of education that are not included in the English denomination, such as correspondence courses, television and video tapes [10]. Therefore, the author states that e-Learning is a modality of 
distance learning, but distance learning is not eLearning.

Currently, the market related to this learning tool is in an exponential growth and development, even considered a phenomenon of global impact. Along this path, there is an increase in investment in this type of education in order to improve and enhance the material and human resources of organizations [11].

The student has a very important role, as it is the central object of the teaching process, with interactivity and physical and temporal separation of e-Learning. It also highlights the importance of the possibility of using several resources from different technologies, which promotes an enrichment to the eLearning environment, due to the variety of communication media it uses [12]. In this sense, institutional effectiveness depends on the methods used and not on the medium used, attributing three specific characteristics to the courses taught through computers: dual modality, which is the ability to provide content through visual and auditory means, a movement that consists in the ability to provide visual content in dynamic formats, such as animation or video and simulation, which is the ability to present environments that respond dynamically and within certain rules, to users' questions [13]. The field of action of e-Learning is on the internet, which is the current means of communication par excellence, being a very active component and present in the daily life of human life [14].

Applying e-Learning to professional training, it is in the business world where this way of teaching and learning has been more receptive, as it is an adequate response to the training and professional development needs of the adult population. ELearning is a tool that catalyzes the organization's potential, empowering it with skills that allow it to obtain a competitive advantage [15]. E-Learning has several advantages, some of which are: the availability and flexibility of teaching, the elimination of geographical dispersion allowing the student to discover a new world through information and communication technologies, the reduction of transportation costs, classes, trainers and food, saving time, the fact that the content can be reused and updated easily and quickly, teaching is tailored to the student's availability, the permanent availability of training content, the reduction of time, the diversification of course offerings and the development of self-study and self-learning skills [16]. On the other hand, the disadvantages pointed out are: the need to have basic technological knowledge, the difficulty and lack of preparation of the trainers, the lack of direct contact between the trainer and the trainee, the reduction of confidence, the need for greater effort to motivating students, the greater responsibility placed on the student, does not generate unforeseen and immediate reactions and the demand for greater discipline and self-organization on the part of the student $[16,17]$.

E-Learning was initially developed as an individual self-taught model, however, it has over time taken advantage of technological infrastructures that enable the interconnection and communication of participants in training processes through communication networks [13]. In this sense, the technologies refer to a huge set of resources that range from electronic mail, more traditional, to the technologies of Learning Management Systems (LMS) [18]. LMS are defined as software products that deal with the dissemination of training. The LMS include different functionalities that ensure administrative support, the management of individuals, trainees and content. Although there are some differences in the LMS, in general, it takes care of the varied courses, registers the entry of the participants, provides the contents according to the manager's guidelines, allows interaction and communication between individuals through synchronous and asynchronous forms of communication. , controls the progress of individuals, recording the length of stay and regularly generating management reports [18].

Training at the Republican National Guard has an essential role, since the service provided by the Institution is guaranteed by the military, making it clear the high importance of acquiring and maintaining specific knowledge, skills and competences for the performance of the police function [19]. Training is defined as a set of educational, pedagogical, training and doctrinal activities aimed at the acquisition and promotion of knowledge, professional technical skills, attitudes and forms of behavior that are necessary and required for the exercise of the proper functions of the military, in the most diverse areas of activity, thus allowing the pursuit of strategic objectives, within the scope of the General Mission of the Republican National Guard. Due to the relevance of the training, it should be seen as a strategic resource, useful to achieve the defined objectives, such as preparing the military for a better performance of his function, improving the quality of service provided to society, improving the weak points and reinforcing your skills [1]. 
The Republican National Guard training model divides training into Basic or Initial Training and Continuous Training. The first guarantees the elementary training necessary to meet the minimum requirements, to access any position at the Republican National Guard at the respective admission level. The second has the objective of guaranteeing the necessary training for performance, with a view to improving and updating the skills acquired previously and the development of skills to obtain a specialization or promotion [19].

Training at the Republican National Guard takes place within the following modalities: Initial, Promotion, Specialization and Qualification and Continuous Improvement and Updating [20].

Initial training, complementing the previous definition, aims to guarantee the preparation of the military as well as professional technical knowledge for entry into the Republican National Guard or for the exercise of functions in a higher category. Promotion training aims to enable the military and civilians to perform functions of a higher level and responsibility, which consists of access to the immediate post. Specialization and qualification training is intended for the military and civilians to obtain or improve their technical and professional knowledge, in order to enable them to exercise sector functions, for which specific knowledge is required. Continuous training for improvement and updating concerns all the training that is given in the unit, establishment and placement body, whose purpose is to maintain or increase individual or collective proficiency levels.

In this segment, and since the present investigation deals with continuous training, it is important to understand which of these four modalities part of it are. Continuous training is a set of organized and institutionalized training processes subsequent to initial training in order to enable adaptation to technological and technical transformations, favour the social promotion of individuals, as well as allow their contribution to cultural, economic and social development [21]. All courses taken after the initial training course are part of continuous training, that is, continuous training includes promotion training, specialization and qualification training and continuous training for improvement and updating.

At the Republican National Guard e-Learning is a tool in development, but it is already present in some courses taught at the institution. The appearance of e-Learning at the Republican National Guard occurred in 2007 with the creation of the
Professional Training Portal of the Ministry of Internal Administration [22].

The definition of e-Learning adopted in Republican National Guard is the process by which the learner learns through content placed on the computer and / or the Internet and in which the trainer, if any, is at a distance using the Internet as a means of communication, which may exist intermediate face-to-face sessions [21].

The first continuous training course using eLearning at the Republican National Guard was the e-Trainers Training Course, conducted in a bLearning regime with a total of 80 hours, divided into 30 classroom hours and 50 hours in e-Learning. The aforementioned course was given to students from Tirocínio for Officers 2007/2008 and to military personnel from the various disciplinary nuclei of Guard School and some leaders, such as the Nature and Environment Protection Service, Administration and Criminal Investigation [23]. In the same year, the Cable Promotion Course also included e-Learning. The 18-week course was divided into two parts, the general part and the special part. The first took place on a face-to-face training basis, where essentially practical subjects were given and the second took place in the Units on a self-training basis with the support of e-Learning [23].

Currently the courses taught by Republican National Guard with resources for e-Learning are the Captain Promotion Course, the Cable Promotion Course, the Criminal Investigation Course and the Criminal Prevention, Community Policing and Human Rights Course. E-Learning serves as a support at the beginning of the aforementioned courses, in order to learn and understand subjects necessary for classroom training. However, the Republican National Guard military needs continuous training in terms of various subjects, whether in the administrative, legal or operational areas. Training is essential to motivate and inspire workers, so that they understand the importance given to them in order to understand their roles and responsibilities, and verify that the host organization is willing to provide the necessary training so that to carry out their duties more appropriately [24]. Thus, it is important that the Republican National Guard provides training actions for the military, in order to learn and update knowledge and maintain motivation at work.

In this context, considering the importance of training within the institution, it is intended to analyze the impact of e-Learning on the training of the Republican National Guard soldiers, seeking to identify positive and negative aspects that may influence a possible implementation of this tool in the training of the institution. 


\section{Materials and Methods}

\subsection{Research Question}

The present investigation intends to answer the following question: How does e-Learning influence the continuous training of the military of the Republican National Guard?

To answer the starting question, the following derived questions were listed, since they would answer the starting question. The derived questions are as follows:

- Q1: What is the importance of continuing education in the Republican National Guard?

- Q2: What are the advantages and disadvantages of implementing eLearning in the continuous training of the military of the Republican National Guard?

- Q3: Does the use of new technologies translate into added value for ongoing training in Republican National Guard?

\subsection{Study Design}

The present investigation presents the deductive method, which starts from the general, and then goes down to the particular, thus reaching a conclusion. The analysis adopted has a mixed nature, quantitative in terms of the number of individuals approached through the questionnaire and qualitative survey, due to the analysis of interviews conducted.

\subsection{Measures}

In relation to the interviews carried out, five entities of the National Republican Guard were targeted whose skills and knowledge fell within the scope of the investigation. Regarding questionnaire surveys, a sample was defined. The target population of the present investigation includes the soldiers of the Lisbon Territorial Command, with my sample consisting of 539 military who responded.

\subsection{Data Analysis}

For the analysis of the interviews in the present investigation, NVivo was used and questionnaire surveys were analyzed using the Statistical Package for the Social Sciences (SPSS).

\section{Results}

For the analysis of the results an approach will be made according to the type of survey carried out. In the first instance, the results of the interviews will be presented, followed by the results of the questionnaire survey.

\subsection{Interviews}

From the interviews, the importance of training is highlighted, evidencing a decisive position in the military, since it allows the oriented updating of the knowledge of the National Republican Guard staff. In this way, it has a marked impact on the service provided by the military, with the need for the current training model to be revised. Continuous training at the Republican National Guard has a high criticality for the professional development of the military, given that, according to the interviewees, it promotes quality in the service, positively affecting the daily activities of the military, increasing individual success and, consequently, organizational success.

With regard to the difficulties evidenced in the provision of training, the lack of time available to receive training is highlighted, due to the strong commitment, the lack of staff and the limitation imposed by the reference time. The lack of incentive is also pointed out as a great difficulty in the provision of training, with regard to the loss of supplements in these periods.

Regarding e-Learning as a training modality, it appears that the tool reflects a stimulus of the training potentials, since it provides the transmission of new knowledge to a larger number of military personnel, which fights geographical dispersion, constituting an added value for the formation of the Republican National Guard.

\subsection{Questionnaires}

The questionnaire survey was disseminated by the military of Lisbon Territorial Command, constituting a population of 1071 military personnel, registering 539 responses, adopting the sample designation. This sample consists of $91.1 \%$ males and $8.9 \%$ females. With regard to the age group of individuals, $20.8 \%$ are aged between 18 and 30 years old, $38.8 \%$ are aged between 31 and 40 years old, $35.3 \%$ are aged between 41 and 50 years old, and $5,2 \%$ between 51 and 60 years old. Regarding the category to which the respondents belong, $0.6 \%$ are civilians, $82.6 \%$ belong to the Guard category, $11.9 \%$ belong to the Sergeant category and only $5 \%$ belong to the Officer category. 


\subsubsection{Statistics on internet and computer usage}

Regarding the use of e-Learning as a learning tool, access to the internet does not translate into a constraint, since 99.3\% (Table 1: Q7) of the respondents answered that they had access to the internet.

Table 1. Access to Internet (Q7)

\begin{tabular}{ccc}
\hline & $\mathbf{N}$ & $\mathbf{\%}$ \\
\hline No & 4 & 0,7 \\
Yes & 535 & 99,3 \\
\hline
\end{tabular}

In respect to the relationship with computers (Table 2: Q8), $86.1 \%$ of respondents use it easily.

Table 2. Use of Computer (Q8)

\begin{tabular}{|c|c|c|}
\hline & $\mathbf{N}$ & $\%$ \\
\hline $\begin{array}{l}\text { I usually have to ask for help to } \\
\text { perform some tasks }\end{array}$ & 7 & 1,3 \\
\hline \multirow{2}{*}{$\begin{array}{l}\text { It is restricted to tasks only } \\
\text { needed }\end{array}$} & 68 & 12,6 \\
\hline & $\mathbf{N}$ & $\%$ \\
\hline $\begin{array}{l}\text { I usually have to ask for help to } \\
\text { perform some tasks }\end{array}$ & 7 & 1,3 \\
\hline $\begin{array}{l}\text { It is restricted to tasks only } \\
\text { needed }\end{array}$ & 68 & 12,6 \\
\hline
\end{tabular}

More than $49 \%$ of the respondents (Table 3: Q13) have a good level of knowledge in terms of computer tools.

Table 3. Knowledge of computer tools (Q13)

\begin{tabular}{ccc}
\hline & $\mathbf{N}$ & $\mathbf{\%}$ \\
\hline Weak & 17 & 3,2 \\
Regular & 133 & 24,7 \\
Good & 265 & 49,2 \\
Very good & 94 & 17,4 \\
Great & 30 & 5,6 \\
\hline
\end{tabular}

Analysing the daily access to the computer at the workplace (Table 4. Q17), 96.5\% responded in accordance with this statement.

Table 4. Daily access to the computer at the workplace (Q17)

\begin{tabular}{ccc}
\hline & $\mathbf{N}$ & $\mathbf{\%}$ \\
\hline No & 19 & 3,5 \\
Yes & 520 & 96,5 \\
\hline
\end{tabular}

Regarding the number of hours working with the computer, $50.8 \%$ work with the computer more than 4 hours a day (Table 5: Q18).

Table 5. Number of hours working with the computer (Q18)

\begin{tabular}{ccc}
\hline & $\mathbf{N}$ & $\mathbf{\%}$ \\
\hline 1h-2h & 142 & 26,3 \\
3h-4h & 123 & 22,8 \\
More than 4h & 274 & 50,8 \\
\hline
\end{tabular}




\subsubsection{Training statistics}

Regarding the importance of training in professional development (Table 6: Q9), 56.5\% of respondents consider training to be very important, with only $2.8 \%$ of respondents receiving more than five training courses given by GNR in the last five years, as opposed to $57,5 \%$ who received less than 3 in the same circumstances (Table 7: Q10)

Table 6. Importance of training in professional development (Q9)

\begin{tabular}{ccc}
\hline & $\mathbf{N}$ & $\mathbf{\%}$ \\
\hline Nothing important & 2 & 0,4 \\
Unimportant & 3 & 0,6 \\
Indifferent & 12 & 2,2 \\
Important & 218 & 40,4 \\
Very important & 304 & 56,5 \\
\hline
\end{tabular}

Table 7. Number of training courses given by GNR (Q109

\begin{tabular}{ccc}
\hline & $\mathbf{N}$ & $\mathbf{\%}$ \\
\hline 0 & 174 & 32,3 \\
Less than 3 & 310 & 57,5 \\
$3-5$ & 40 & 7,4 \\
More than 5 & 15 & 2,8 \\
\hline
\end{tabular}

Analysing Q11 (Table 8) on the need for training, it appears that $96.7 \%$ of respondents say that the lack of training represents a gap in their professional path and show its clear importance.

Table 8. Perceptions on the need for training (Q11)

\begin{tabular}{ccc}
\hline & $\mathbf{N}$ & $\mathbf{\%}$ \\
\hline No & 18 & 3,3 \\
Yes & 521 & 96,7 \\
\hline
\end{tabular}

Moreover, $53.6 \%$ say they are not satisfied with the training policy promoted by the Institution (Table 9: Q12).

Table 9. Level of satisfaction with the training promoted by the Institution (Q12)

\begin{tabular}{ccc}
\hline & $\mathbf{N}$ & $\mathbf{\%}$ \\
\hline Nothing satisfied & 133 & 24,7 \\
Not satisfied & 289 & 53,6 \\
Indifferent & 45 & 8,3 \\
satisfied & 69 & 12,8 \\
Very satisfied & 3 & 0,6 \\
\hline
\end{tabular}


Analysing the areas with the greatest need for training (Table 10: Q15), it appears that $50.1 \%$ corresponds to the operational area, followed by the administrative area with $27.1 \%$ and the legal area with $17.8 \%$.

Table 10. Area of training (Q15)

\begin{tabular}{ccc}
\hline & $\mathbf{N}$ & $\mathbf{\%}$ \\
\hline Administrative & 146 & 27,1 \\
Computing & 1 & 0,2 \\
Legal & 96 & 17,8 \\
Operational & 270 & 50,1 \\
All & 26 & 4,8 \\
\hline
\end{tabular}

It is also clear that the tools chosen for the transmission of knowledge are the demonstrative videos with $47.9 \%$, the updated documents with $27.3 \%$ and the videos (recorded lessons) with $18.2 \%$ (Table 11: Q16).

Table 11. Tools for the transmission of knowledge (Q16)

\begin{tabular}{ccc}
\hline & $\mathbf{N}$ & $\mathbf{\%}$ \\
\hline Videos (recorded lessons) & 98 & 18,2 \\
Demo videos & 258 & 47,9 \\
Updated documents & 147 & 27,3 \\
Games & 3 & 0,6 \\
Practical classes & 24 & 4,5 \\
All & 9 & 1,7 \\
\hline
\end{tabular}

\subsubsection{Statistics related to e-Learning}

From the analysis to Q14 (Table12) it appears that only 6.5\% of respondents are unaware of the e-Learning tool, compared to the remaining $93.5 \%$.

Table 12. Perceptions about the e-Learning tools (Q14)

\begin{tabular}{ccc}
\hline & $\mathbf{N}$ & $\mathbf{\%}$ \\
\hline No & 35 & 6,5 \\
Yes & 504 & 93,5 \\
\hline
\end{tabular}

With regard to the preference of the learning method, 76.4\% (Table13: Q19) claim to choose the use of new technologies to receive continuous training.

Table 13. Learning Method (Q19)

\begin{tabular}{ccc}
\hline & $\mathbf{N}$ & $\mathbf{\%}$ \\
\hline $\begin{array}{c}\text { Traditional } \\
\text { methods }\end{array}$ & 127 & 23,6 \\
$\begin{array}{c}\text { Resort to new } \\
\text { technologies }\end{array}$ & 412 & 76,4 \\
\hline
\end{tabular}

A high percentage $(87 \%)$ of respondents claim to be willing to attend courses taught through online platforms (Table14: Q20).

Table 14. Willingness to attend online courses in the future (Q20)

\begin{tabular}{ccc}
\hline & $\mathbf{N}$ & $\mathbf{\%}$ \\
\hline No & 21 & 3,9 \\
I don't know & 49 & 9,1 \\
Yes & 469 & 87 \\
\hline
\end{tabular}




\section{Discussion}

The data obtained through the interviews and the questionnaire survey allow relevant criticisms to be made in order to determine certain conclusions and obtain answers to the present investigation. In this sense, the results obtained through the interviews help to obtain a personal and real perspective from the interviewees, whose functions are highly relevant to the topic. On the other hand, the results of the questionnaire survey provide a holistic view of the topic within the Institution, as it covers the main stakeholders about continuing education.

Continuous training at GNR has a high criticality for the professional development of the military, given that, according to the interviewees, it promotes quality in the service, positively affecting the daily activities of the military, increasing individual success and, consequently, organizational success. In this line of reasoning, training in organizations has a great weight in terms of improving professional skills, updating knowledge and also responding to problems and failures in the execution of work [6].

Training becomes essential to fill the gaps in areas with the greatest need for training and for the constant adaptations to the environment that have been occurring over time. According to the Commander of Lisbon Territorial Command, the military is not receiving the necessary training due to the difficulty of concentrating the staff with this current training model, pointing to e-learning as a useful tool to address certain gaps.

In this sense, e-Learning is characterized by a set of solutions made available by internet technologies, which facilitate and enhance the knowledge and development of individuals [10]. Its field of action is the internet, which is the current means of communication, being very active and present in the daily life of human life [14].

The analysis of the questionnaire survey proves that the military needs training, evidencing their dissatisfaction with the institution's promoted training policy, making it categorical to create alternative mechanisms to overcome this problem. This dissatisfaction results in large part from the fact that the institution does not promote regular training, since there are many objectives for its achievement. The questionnaires show that in the last five years, $32.3 \%$ had no training and $57.5 \%$ had less three, these numbers being very low for an institution like the National Republican Guard. Through the interviews, it appears that the great current problem is the impossibility of concentrating the number of troops and the great geographical dispersion of the soldiers of the National Republican Guard. In this direction, one of the great advantages of e-Learning is the possibility of reaching a large number of geographically dispersed individuals, allowing them not to be far from the workplace.

It should be noted that, based on the results of the questionnaire survey, it appears that $96.5 \%$ of respondents have daily access to a computer at the workplace, and $99.3 \%$ have access to the internet. In this light, it is confirmed that $86.1 \%$ of respondents have a good relationship with computers and $87 \%$ are willing to attend training courses using online platforms. Regarding military personnel who are not in favour of new technologies, they must have extra training in this sense, so that they become familiar with the new technologies and learn the basic concepts, in order to overcome their difficulties. As such, the military is in a position to receive training through technological tools.

With regard to the main vulnerabilities pointed out to the learning tool, the need to have basic technological knowledge becomes a major obstacle to the use of computer tools, although this can be overcome with the effort and willpower on the part of the military to develop their technical capabilities related to the use of said equipment. In addition, the need for greater effort to motivate the military is also a vulnerability, however, the lack of training and discontent on the part of them leads to an increase in their commitment, since they recognize the need to obtain training, thus resulting in self-motivation.

Regarding the practical component of training, it should be noted that it is a complement to the theoretical part, since it results from the confirmation of the knowledge obtained. In this logic, its importance in the operational aspect is added, making compliance with it essential in order to guarantee the 
updating of the procedures necessary for the operational activity.

Through the analysis of the results of the interviews, it is evident that e-Learning allows knowledge to be transmitted from any location, with a saving of time, and it may be possible, later, to be confirmed by groups, that is, to form groups of 15 to 20 military personnel and carry out practical activities, in order to confirm the knowledge assimilated through the distance training tool.

That said, it appears that the e-Learning tool represents an asset for continuous training, since it is a catalyst for the potential of the institution's human resources, thus promoting organizational development and success.

\section{Conclusions}

The present investigation was intended to deepen theoretically and empirically the problem of e-Learning in the continuous training of the soldiers of the Republican National Guard. The literature review and the empirical investigation allowed to obtain essential data that supported this investigation.

All the actions developed in this investigation allowed to fulfil the objectives initially proposed, which were stated in the form of research questions to assist in the exposure of the results obtained. Answering the question from the beginning, eLearning emerges as a tool with several potentialities for the Institution and for the military. The geographical dispersion and the difficulty of concentrating the staff make e-Learning essential for continuous training, allowing them easy access to training. The fact that it is possible for the military to have training from their workplace suppresses the need to travel, which reduces transportation and food costs, allowing the continuation of the performance of their duties. In addition, e-Learning allows for easy schedules, different learning rhythms, sharing of experiences between trainees and also provides familiarization with technology. Finally, e-Learning positively influences the continuous training of the Republican National Guard, as it contributes to the enrichment of the military's knowledge, developing their skills and increasing individual and organizational success.

\section{References}

[1]. Guarda Nacional Republicana. Bases Gerais da Formação da GNR; Lisboa: Guarda Nacional Republicana, 2008a.

[2]. Jamba, I. C. Políticas e práticas de formação profissional contínua: $\mathrm{O}$ caso de um grupo de empresas de consultoria e engenharia. Dissertação de Mestrado em Gestão Estratégica de Recursos Humanos, Instituto Politécnico de Setúbal, Setúbal, 2018.

[3]. Carvalho, R. F. G. A formação contínua na Guarda Nacional Republicana: a sua importância no desempenho dos militares. Trabalho de investigação aplicada, Mestrado em Ciências Militares, Academia Militar, Lisboa, 2016.

[4]. Kovács, I. Tendências de evolução dos sistemas produtivos, orientações para a educação e formação. Formar, $n^{\circ}$ 50, 3-16, 2005.

[5]. Parente, C. Construção social das competências profissionais: dois estudos de caso em empresas multinacionais do sector metálico. Dissertação de Doutoramento, Porto, Faculdade de Letras da Universidade do Porto, Porto, 2003.

[6]. Cardim, J. C. Gestão da Formação nas Organizações 2.a ed.; Lisboa: Lidel- edições técnicas, lda, 2012.

[7]. Sousa, A. P., \& Cordeiro, J. P. Novas tecnologias aplicadas à formação : Estudo de caso na agência para a modernização administrativa. Dosalgarves: A Multidisciplinary e-Journal, 25, 60-83, 2015.

[8]. Camara, P. B., Guerra, P. B., \& Rodrigues, J. V. Humanator: Recursos Humanos e Sucesso Empresarial 5.a ed.; Lisboa: Publicações Dom Quixote, 2003.

[9]. Sousa, F. A. B. de C. E-Learning na defesa: contributos para um modelo de desenvolvimento. Trabalho de investigação individual, Instituto de Estudos Superiores Militares, Lisboa, 2011.

[10]. Rosenberg, M. Pilares de uma estratégia de sucesso; HSM Management, 2001.

[11]. Custódio, V. M. R. V. O modelo de e-Learning implementado na formação profissional dos militares: Avaliação da eficácia; ual, Instituto Universitário Militar, Lisboa, 2018.

[12]. Khan, B. The Global e-Learning framework. In S. Mishra (Ed.), Stride hanbook 8 e-Learning; New Delhi: IGNOU, 2009. Available online: http://www.ignou.ac.in/userfiles/Handbook 8 pdf compressed.pdf (accessed on 29/03/2020).

[13]. Clark, R. C. Aprendizagem multimédia em cursos de e-Learning. In G. Miranda, Ensino Online e Aprendizagem Multimédia (pp. 238-285). Lisboa: Relógio d'Agua, 2009. 
[14]. Cruz, P. M. Pedagogia do E-Learning : um ambiente de aprendizagem online para professores e formadores. Dissertação de Mestrado em Tecnologias da Informação e da Comunicação, Escola Superior de Educação Jean Piaget, Vila Nova de Gaia, 2014.

[15]. Miranda, G. Ensino online e aprendizagem multimédia. Lisboa: Relógio d'Agua, 2009. Available online: https://doi.org/10.1177/1742766510373715 (accessed on 07/04/2020).

[16]. Machado, S. I. da M. A. A Formação Profissional no Contexto Empresarial: Proposta de um Sistema de ELearning. Mestrado em Ciências do Trabalho e Relações Laborais, Instituto Universitário de Lisboa, Lisboa, 2010.

[17]. Caridade, M. E. Formação profissional: Concepção, implementação e avaliação de cursos e-Learning. Mestrado em Educação, Universidade de Lisboa, Lisboa, 2012.

[18]. Lagarto, J., \& Andrade, A. Sistemas de gestão de aprendizagem em e-Learning. In G. Miranda, Ensino Online e Aprendizagem Multimédia; Lisboa: Relógio d'Agua, 2009.
[19]. Guarda Nacional Republicana. Diretiva $n^{\circ}$ 05/CDF/2010 de 25 de março: Formação Contínua de Aperfeiçoamento, 2010.

[20]. Guarda Nacional Republicana. Plano Anual de Formação; Lisboa: Guarda Nacional Republicana, 2019a.

[21]. Guarda Nacional Republicana. Glossário de Formação, de Educação, Treino e de Doutrina; Lisboa: Guarda Nacional Republicana, 2008 b.

[22]. Rádio e Televisão de Portugal. Ministério da Administração Interna cria Portal de Formação para forças segurança. In Rádio e Televisão de Portugal, 2006. Available online: https://www.rtp.pt/noticias/pais/ministerio-daadministracaointerna-cria-portal-de-formacao-paraforcas-seguranca n37953 (accessed on 15/04/2020).

[23]. Augusto, T. A Formação Contínua na GNR com recurso às novas tecnologias (eLearning). Mestrado em Ciências Militares - Especialidade Segurança, Academia Militar, Lisboa, 2009.

[24]. França, V. M. Contributo da formação para o elevado desempenho organizacional: Um estudo de caso de uma entidade formadora. Dissertação de Mestrado em Gestão, Universidade de Coimbra, Coimbra, 2013.

Creative Commons Attribution License 4.0 (Attribution 4.0 International, CC BY 4.0)

This article is published under the terms of the Creative Commons Attribution License 4.0

https://creativecommons.org/licenses/by/4.0/deed.en US 